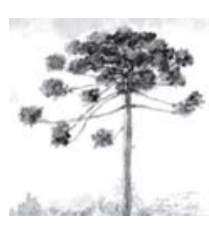

\title{
EFFECT OF PHYSICOCHEMICAL PROPERTIES AND ATTACHMENT SURFACES ON BIOFILMS IN CASSAVA MILL EFFLUENT POLLUTED OLOSHI RIVER, NIGERIA
}

\author{
Efeito das propriedades físico-químicas e de características de adesão às \\ superficies sobre biofilmes formados em um efluente de moinho de \\ mandioca às margens do rio Oloshi, Nigéria
}

\section{Victor Oluoha Nwaugo ${ }^{1}$, Reginald Azuonye Onyeagba ${ }^{2}$, Solomon Nnanna Umeham ${ }^{3}$, Nelson Azu ${ }^{4}$}

\footnotetext{
${ }^{1}$ Dept of Microbiology, Abia State University, Uturu-Nigeria, e-mail: vonwaugo@yahoo.com

${ }^{2}$ Dept of Microbiology, Abia State University, Uturu-Nigeria, e-mail: azuonyeagba@yahoo.com

${ }^{3}$ Dept of Environmental Biology, Abia State University, Uturu-Nigeria, e-mail: soloumeham@yahoo.com

${ }^{4}$ Dept of Microbiology, Ebonyi State University, Abakiliki - Nigeria, e-mail: ancfountains@yahoo.com
}

\begin{abstract}
The effects of physicochemical properties and attachment surface characteristics on biofilm formed in a cassava mill effluent of the polluted Oloshi River (Nigeria) was investigated. Concerning to physicochemical properties, the Total Dissolved Solids (TDS), Total Suspended Solids (TSS), and Dissolved Oxygen (DO) were significantly affected with higher values in the discharge point (DP) than in the downstream points (DS). Values for these properties in samples from upstream (US) sites were lower than in the DP, except for DO that was higher. Klebsiella spp., Corynebacterium spp., Moraxella spp., Acinetobacter spp., and Saccharomyces spp. were absent in the US, but were found from the DP though the DS. Regarding to the bioloads, DS I has presented the highest bacterial counts, followed by the DS II, while the lower counts were obtained in US. Again, in a general form, higher biofilm contents have been observed in DS I, followed by DS II, and lower in US. In all sampling sites, wood surfaces had the highest biofilm bacterial counts followed by the plastic surfaces before the glass and metallic surfaces. In that order, higher biofilm bacterial counts then water column counts were observed. The obtained results let us to infer that the availability of nutrients and the nature of attachment surfaces directly influence in the biofilm formation in such analyzed ecosystems.
\end{abstract}

Keywords: Biofilm; Attachment surfaces; Mill effluent. 


\section{Resumo}

Os efeitos das propriedades físico-químicas e das características de adesão às superfícies sobre biofilmes formados em um efluente oriundo de moinho de mandioca às margens do rio Oloshi, Nigéria, foram investigados. Em relação às propriedades físico-químicas, os valores de Sólidos Totais Dissolvidos (TDS), Sólidos Totais Suspensos (TSS) e Oxigênio Dissolvido (DO) foram significativamente mais elevados no ponto de descarga $(D P)$ que em pontos de coleta "rio-abaixo" (DS). Valores para essas mesmas propriedades foram menores em pontos situados "rio-acima", com exceção de DO que foi significativamente maior. Klebsiella spp., Corynebacterium spp., Moraxella spp., Acinetobacter spp. e Saccharomyces spp. não foram detectadas em US; mas foram isoláveis desde o DP até o DS. Em relação à carga bacteriana, o ponto DS I apresentou as maiores contagens, seguidas do ponto DS II, ao passo que as menores contagens foram obtidas em US. De forma geral, as maiores formações de biofilme foram observadas em DS I, seguido de DS II; as menores foram observadas em US. Em todos os sitios amostrais, as superfícies de madeira apresentaram maiores contagens bacterianas, seguidas por superfícies plásticas, vítreas e metálicas. As contagens celulares associadas aos biofilmes foram maiores que nas colunas de água. Os resultados obtidos levam a inferir que a disponibilidade de nutrientes e a natureza das superfícies de adesão são determinantes na formação de biofilmes bacterianos no ecossistema analisado.

Palavras-chave: Biofilme; Superfície de adesão; Efluentes de moinhos.

\section{INTRODUCTION}

A biofilm is an assemblage of surfaceassociated microbial cells enclosed in an extracellular polymeric matrix Darlon (1). This association is usually irreversible and can form on a variety of materials including living tissues, wood, glass, plastics, etc. However, the nature of the biofilm, both in materials and organisms involved, is dependent on the environment and available materials $(1,2,3)$. The nature of the pollutant in the environment also influences the composition, ease of formation and organisms involved Buswell et al. (4, 5, 6). In an aquatic environment, the physicochemical properties will influence the type and population of bacteria in the available biofilm Bos et al. (7) McPeters et al. (8) Parsek (9).

The role of Biofilm in disease distribution and generation of new foci have been explained ( 9 , 10,11). The study of biofilms, especially in a public utilizing environment becomes of great importance in Aquatic Microbiology. Again, the important role of water bodies in human existence can not be overemphasized. It therefore becomes important to protect such water bodies. Factors which influence survival of organisms in water also influences biofilm formation and survival $(12,13)$.

This work therefore set out to investigate the types of bacterial species present in cassava effluent polluted and cassava steepping portions of Oloshi River, Egbema. This was done in relation to the physicochemical parameters of the water body concerned, as information concerning aquatic biofilms in Nigeria is either scanty or non-existent.

\section{MATERIALS AND METHODS}

The study area is Egbema, which is a community in the Niger Delta Area of Southern Nigeria. The Oloshi River is an all season stream. It serves the domestic and recreational needs of the people for the purposes of drinking, washing, bathing, fishing, swimming, cassava steepping, etc.

Two cassava processing plants are located within the opposite banks of the river, into which they empty their effluents (cassava juice). 


\section{SAMPLE COLLECTION}

Samples were collected from four points based on distances from the discharge point. Upstream sample was collected $120 \mathrm{~m}$ up stream from the discharge point (DEP). Down Stream I (DSI) was $120 \mathrm{~m}$ down the river course after the Discharge Point while Down Steam II (DSII) was taken from a point $120 \mathrm{~m}$ down stream from DSI.

Biofilms were collected from four different material surfaces ranging from Glass, wood, Iron (metal) and Plastic. Biofilm from each attachment surface was scrapped into sterile universal bottles with screw cap using sterile blades. These were properly labeled according to material and sampling location before transporting to the laboratory for analysis within 1-2 hours of collection.

Normal water column samples were equally collected at each sampling point. For both physicochemical properties and bacteriological analysis. Samples were collected from 3 different spots within the same sampling point and bulked.

\section{PHYSICOCHEMICAL PARAMETER MEASUREMENT}

The physicochemical parameters measured include $\mathrm{pH}$, temperature, Total Dissolved Solids. (TDS), Total Suspended Solids (TSS), Dissolved Oxygen (DO), and Biological Oxygen Demand (BOD). The others were Sulphate $\left(\mathrm{SO}_{4}\right)$, Phosphate $\left(\mathrm{PO}_{4}\right)$, Nitrate $\left(\mathrm{NO}_{3}\right)$, Conductivity and Turbidity. The metallic ions $(\mathrm{K}, \mathrm{Mg}, \mathrm{Na}$ and $\mathrm{Ca}$ ) were determined using the Atomic Absorption Spectrophotometric (AAS) method as described by APHA (14) using HACH/ D2/2010 Spectrophotometer. The TDS, TSS, $\mathrm{PO}_{4}, \mathrm{NO}_{3}$ and $\mathrm{SO}_{4}$ were equally determined spectrophotometrically (APHA [14]. The DO and BOD were determined by the winkler's titrometric method while $\mathrm{pH}$, temperature and conductivity were determined in situ using the Jenway HANNA 1910 multipurpose tester. The turbidity was done using spectromic B0D meter.
The Cyanogenic potentials of the water samples were determined according to Brudburg et al. (15) using the elution method of sodium picrate solution.

\section{MICROBIOLOGICAL ANALYSIS}

The collected samples were inoculated on different culture media using the spread plate technique as described by Chessbrough (16) after serial dilution. The media used included Nutrient Agar for Total Heterotrophic Bacteria, (THB), the McConkeey Agar for Coliforms (CB), and Mineral Salt Agar modified with cassava effluent to obtain Cassava Effluent Utilizing Bacteria (CEUB).

The collected biofilms were equally inoculated on those same media to obtain the same groups of bacteria. Again, ten water samples collected from each sampling point at weekly intervals were inoculated on Tryptone Soil Agar to obtain occurrence rate of each organism using the same spread plate method of inoculation.

\section{RESULTS}

The temperature ranged from 28.4 to $29.3^{\circ} \mathrm{C}$ upstream to DSII with the highest point being DSI. There was no significant changes in the metallic ions analysis. Results of the physicochemical parameters are shown in Table I, While the US $\mathrm{pH}$ was 6.7, the DFP had 8.2 and the DSII was 7.3. The TDS, TSS and $\mathrm{BOD}_{5}$ were significantly affected as they increased in values with the highest in the DP and lowest in US. These decreased with flow down the course of the river. The DO decreased from the DFP but gradually improved thereafter. The $\mathrm{PO}_{4}$, $\mathrm{NO}_{3}$, and $\mathrm{SO}_{4}$ had non-significant increase from the DFP $(\mathrm{P}>0.05)$. However, turbidity and cyanogenic potential were also higher at the DFP but conductivity was higher at DSII. (Table 1). 
Victor Oluoha Nwaugo; Reginald Azuonye Onyeagba;

TABLE 1 - Physicochemical Parameter of the water samples

\begin{tabular}{|c|c|c|c|c|}
\hline PARAMETER & US & $\mathrm{DP}$ & DSI & DSII \\
\hline PH & $6.7 \pm 0.21^{\mathrm{a}}$ & $8.0 \pm 0.63^{b}$ & $7.56 \pm 0.32^{\mathrm{b}}$ & $7.2 \pm 0.21^{\mathrm{ab}}$ \\
\hline Temp ${ }^{\circ} \mathrm{C}$ & $28.4 \pm 0.40^{\mathrm{a}}$ & $29.1 \pm 0.30^{\mathrm{b}}$ & $30.3+$ & 29.3 \\
\hline TDS mg/1 & $256 \pm 2.02^{\mathrm{a}}$ & $1240 \pm 0.31^{\mathrm{b}}$ & $705 \pm 0.70^{c}$ & $510 \pm 0.50^{\mathrm{b}}$ \\
\hline TSS mg/1 & $51 \pm$ & $73 \pm 0.30^{\mathrm{b}}$ & $63 \pm 0.30^{\mathrm{b}}$ & $54 \pm 0.30^{a}$ \\
\hline $\mathrm{DO} \mathrm{mg} / \mathrm{l}$ & $6.8+0.01^{\mathrm{a}}$ & $4.3 \pm 0.25^{\mathrm{b}}$ & $5.4 \pm 0.70^{c}$ & $6.0 \pm 0.30^{\mathrm{ac}}$ \\
\hline BOD mg/l & $54 \pm 0.30^{\mathrm{a}}$ & $8.3+0.60^{b}$ & $75 \pm 0.30^{\mathrm{b}}$ & $62 \pm 0.50^{\mathrm{a}}$ \\
\hline $\mathrm{PO}_{4} \mathrm{mg} / \mathrm{l}$ & $0.08 \pm 0.01^{\mathrm{a}}$ & $0.10 \pm 0.20^{\mathrm{b}}$ & $0.95 \pm 0.20^{c}$ & $0.85 \pm 0.30^{c}$ \\
\hline $\mathrm{NO}_{3} \mathrm{mg} / \mathrm{l}$ & $1.04 \pm 0.20^{\mathrm{a}}$ & $1.14 \pm 0.10^{\mathrm{b}}$ & $1.52 \pm 0.35^{c}$ & $1.06 \pm 0.30^{\mathrm{a}}$ \\
\hline $\mathrm{SO}_{4} \mathrm{mg} / 1$ & $26.1+0.30^{\mathrm{a}}$ & $26.8 \pm 0.10^{a}$ & $26.6 \pm 0.20^{a}$ & $26.3 \pm 0.20^{\mathrm{a}}$ \\
\hline $\mathrm{Na} \mathrm{mg} / \mathrm{l}$ & $0.84 \pm 0.30^{\mathrm{a}}$ & $0.85 \pm 0.20^{\mathrm{a}}$ & $0.84 \underline{ \pm} 0.40^{\mathrm{a}}$ & $0.84 \pm 0.20^{\mathrm{a}}$ \\
\hline $\mathrm{K} \mathrm{mg} / \mathrm{l}$ & $1.42 \pm 0.30^{\mathrm{a}}$ & $1.45 \pm 0.40^{\mathrm{a}}$ & $1.43 \pm 0.20^{\mathrm{a}}$ & $1.42 \pm 0.50^{\mathrm{a}}$ \\
\hline $\mathrm{Mg} \mathrm{mg/1}$ & $1.04 \pm 0.40^{\mathrm{a}}$ & $1.05 \pm 0.20^{\mathrm{a}}$ & $1.04 \pm 0.10^{\mathrm{a}}$ & $1.04 \pm 0.20^{\mathrm{a}}$ \\
\hline $\mathrm{Ca} \mathrm{mg/1}$ & $22.1 \pm 0.30^{\mathrm{a}}$ & $25.0 \pm 0.50^{\mathrm{b}}$ & $24.1 \pm 0.20^{\mathrm{ab}}$ & $23.4 \pm 0.10^{\mathrm{a}}$ \\
\hline
\end{tabular}

*Figure followed by the same alphabets are not significantly different but those followed different alphabets are significantly different.

The prevalence of the organisms as reported in Table 2 shows that the highest prevalence was at DSI followed by DSII before DFP.

The lowest prevalence was in the US where Klebsiella, Corynebacterium, Morexella, Acinetobacter and Saccharomyces species were absent (Table 2).

TABLE 2 - Occurrence of Microbial species in water samples analysed

\begin{tabular}{lllll}
\hline ORGANISMS & US & DF & DSI & DSII \\
\hline Entrobacter sp & $3(30.00)$ & $5(50.00)$ & $4(40.00)$ & $2(20.00)$ \\
Staphylococcus sp & $4(40.00)$ & $6(60.00)$ & $7(70.00)$ & $4(40.00)$ \\
Lactobacillus & $2(20.00)$ & $5(50.00)$ & $7(70.00)$ & $4(40.00)$ \\
Micrococcus & $2(20.00)$ & $4(40.00)$ & $5(50.00)$ & $3(30.00)$ \\
Bacillus & $8(80.00)$ & $10(100.00)$ & $10(100.00)$ & $10(100.00)$ \\
Alcaligenes & - & $2(20.00)$ & $4(40.00)$ & $2(20.00)$ \\
Klebsiella & - & $3(30.00)$ & $5(50.00)$ & $2(20.00)$ \\
Carynebacterium & - & $3(30.00)$ & $4(40.00)$ & $2(20.00)$ \\
E. coli & $3(30.00)$ & $5(50.00)$ & $2(20.00)$ & $3(30.00)$ \\
Acinetobacter & - & $3(30.00)$ & $4(40.00)$ & $2(20.00)$ \\
Marexalla & - & $3(30.00)$ & $3(30.00)$ & $1(10.00)$ \\
Pseudomonas & $1(10.00)$ & $3(30.00)$ & $4(40.00)$ & $2(20.00)$ \\
Sacchromyces & - & $5(50.00)$ & $7(70.00)$ & $3(30.00)$ \\
\hline
\end{tabular}

- Not observed

* Figures in bracket represent percentage occurrence in samples.

The bioload of the various groups of organisms showed that DSI had the highest bioload in each bacterial group estimated. The most prevalent were the THBC, followed by the CEUB while the lowest was the coliforms (CBC) except in the US where CEUB was very similar to the CBC (Table 3). 
Effect of physicochemical properties and attachment surfaces on

biofilms in cassava mill effluent polluted Oloshi river, Nigeria

TABLE 3 - Biolad of the varius bacterial groups estimated in the water column

\begin{tabular}{lllll}
\hline $\begin{array}{l}\text { BACTERIAL } \\
\text { GROUP }\end{array}$ & US & DP & DSI & DSII \\
\hline THBC & $4.7 \times 10^{4} \pm 0.20^{\mathrm{a}}$ & $4.8 \times 10^{5+0.30}$ & $5.7 \times 10^{6} \pm 0.30^{\mathrm{bc}}$ & $4.2 \times 10^{6} \pm 0.23^{\mathrm{b}}$ \\
CBC & $2.2 \times 10^{2} \pm 0.40^{\mathrm{a}}$ & $2.3 \times 10^{3} \pm 0.40^{\mathrm{b}}$ & $2.1 \times 10^{3} \pm 0.30 \mathrm{~b}$ & $2.7 \times 10^{3} \pm 0.40^{\mathrm{c}}$ \\
CEUBC & $2.4 \mathrm{X} 10^{2} \pm 0.20 \mathrm{a}$ & $2.4 \mathrm{X} 10^{4} \pm 0.35^{\mathrm{b}}$ & $2.7 \mathrm{X} 10^{4} \pm 0.30 \mathrm{~b}$ & $2.9 \times 10^{4} \pm 0.43^{\mathrm{c}}$ \\
\hline
\end{tabular}

*Figure are mean values of five times sampling

THBC $=\quad$ Total Heterotrophic Bacteria Count

$\mathrm{CBC}=\quad$ Coliform Bacterial Count

CEUBC $=\quad$ Cassava Effluent Utilizing Bacterial Count

Table 4 shows that there were significant variations in the number of organisms observed on the different attachment surfaces for the Biofilms. The lowest units were observed in the US with metallic surface having the least $\left(3.7 \times 10^{5}\right)$, followed by glass $4.1 \times 10^{5}$ and the highest in wooden surface $\left(4.8 \times 10^{5}\right)$. Generally, biofims collected from surfaces in DSI sampling point had the highest biofilm bioloads with counts ranging from $7.3 \times 10^{6}$ (wooden), $6.7 \times 10^{6}$ (plastic) to $5.5 \times 10^{6}$ (glass) and $5.1 \times 10^{5}$ (metallic surface) (Table 4). Values for biofilm bioload generally decreased in the DSII according to the same attachment surface gradient (Table 5).

TABLE 4 - Biolad of Biofilm on varius attachment surfaces

\begin{tabular}{lllll}
\hline SITE & WOOD & GLASS & METALLIC & PLASTIC \\
\hline US & $4.8 \times 10^{5} \pm 0.35^{\mathrm{a}}$ & $4.1 \times 10^{5}+0.42^{\mathrm{b}}$ & $3.7 \times 10^{5}$ & $4.5 \times 10^{5} \pm 0.20^{\mathrm{ab}}$ \\
DP & $5.1 \mathrm{X} 10^{4} \pm 0.40^{\mathrm{a}}$ & $4.7 \times 10^{3}+0.20^{\mathrm{b}}$ & $5.5 \times 10^{3}$ & $5.2 \times 10^{3} \pm 0.30^{\mathrm{c}}$ \\
DSI & $7.3 \mathrm{X} 10^{6} \pm 0.20^{\mathrm{a}}$ & $5.5 \times 10^{6} \pm 0.50^{\mathrm{c}}$ & $5.1 \times 10^{5} \pm 0.30^{\mathrm{c}}$ & $6.7 \mathrm{X} 10^{6} \pm 0.30^{\mathrm{a}}$ \\
DSII & $7.1 \mathrm{X} 10^{4} \pm 0.20^{\mathrm{a}}$ & $5.2 \times 10^{4}+0.20^{\mathrm{c}}$ & $4.8 \times 10^{4} \pm 0.40^{\mathrm{c}}$ & $6.2 \times 10^{4} \pm 0.30^{\mathrm{b}}$ \\
\hline
\end{tabular}

Figure are mean of five times sampling

$\mathrm{US}=$ Upstream

$\mathrm{DP}=$ Discharge Point

$\mathrm{DSI}=$ Downstream I

DSII $=$ Downstream II

TABLE 5 - Organisms in Biofilm

\begin{tabular}{lcccc}
\hline ORGANISMS & US & DF & DSI & DSII \\
\hline Enterobacter sp & + & + & + & + \\
Staphylococcus sp & + & + & + & + \\
Lactobacillus sp & + & + & + & + \\
Micrococcus sp & + & + & + & + \\
Bacillus sp & + & + & + & + \\
Alcaligenes sp & - & + & + & + \\
Klebsiella sp & - & + & + & + \\
Carynebacterium sp & - & + & + & + \\
E. coli & + & + & + & + \\
Acinetobacter sp & - & + & + & + \\
Marexalla $\mathrm{sp}$ & - & + & + & + \\
Pseudomonas $\mathrm{sp}$ & + & + & + & + \\
Sacchromyces & - & & + & + \\
\hline
\end{tabular}

$+=\quad$ Present in Biofilms of the sampling in site

$-=$ Not present in Biofilms at the sampling site 
Again, in all the sampling points, wood surface had the highest biofilm bioloads than the plastic while the least was metallic surface. This correlated well with TDS and TSS. However, organisms seen in the water column were the same as those in he biofilms at each sampling point though biofilm bioloads were higher than water column bioloads, they correlated positively.

\section{DISCUSSION}

Results of analysis of the physicochemical properties showed that the cassava effluent modified the properties of the Oloshi River. The most affected parameters were the BOD, TSS, TDS and DO which were highest at the DFP and decreased with distance away downstream. The high TDS and TSS could be attributed to the components of the cassava effluent which required some oxygen for oxidation causing low DO and high BOD. The high turbidity of the DFP was because of these dissolved and suspended solids too. Adewoye et al. (17), Chinyere (18) and Nwaugo et al. (19) stated that concentrations of any given pollutant are highest at the point of discharge. This was also the case of the Cyanogenic potential estimated in the river which was considerably low. Adewoye et al. (17) and Nwabueze (20) had reported cyanogenic potential values of $2.77-4.91 \mathrm{HCN} \mathrm{mg/100g}$, while only $1.03 \mathrm{HCNmg} / 100 \mathrm{~L}$ was observed at the DFP in this work. This could be expected as Adewoye et al. (17) and Nwabueze (20) worked in cassava tubers and wastes directly without dilution while the contaminated Oloshi River was the subject of this work. The slight alkalinity of the downstream sample agrees with Akani et al. (21) who reported that $\mathrm{NH}_{3}$ is produced in cassava fermentation which gives the highly offensive odour. This $\mathrm{NH}_{3}$ simply dissolves in the aquatic habitat changing the $\mathrm{pH}$. However, the water volume was too much to show marked charge in the $\mathrm{pH}$.

Most of the organisms observed in this work had been implicated in cassava wastes and products degradation. Corynebacterium, Acinetobacter, Klebsiellia, Saccharomyces, Lactobacillus and Bacillus species have been associated with cassava fermentation. Others include Alcaligenes, Micrococcus and Morexella species (Abiona et al.
(22), Oyewole (23), Desse (24). On the other hand, Nwachukwu and Otukunefor (25), Prescot et al. (26) and Nwaugo et al. (20) reported that E. coli, Staphylococcus, Bacillus and Micrococcus species are common contaminants of water bodies especially those used for various domestic purposes. Prevalence of organisms according to sampling points showed that some organisms were introduced into the water with the cassava effluent as they were absent in the US. These were mainly Klebsiella, Corynebacterium, Morexella and Saccharomyces species. This tends to agree with Nwaugo et al. $(27,28)$ and Ezenobi and Okpokwasili (29) that some industrial wastes carry some microorganisms into the receiving sink, water bodies inclusive. This addition was collaborated by the increase of bioload observed from the DFP downstream.

Observations showed that the DFP with its high concentration of the cassava effluent had lower bioload than DSI and DSII. This could be attributed to the state of the cassava waste and volume. The wastes could have been too toxic for immediate metabolism hence required time for oxidation and dilution to a more condusive volume and state. However, the increase in bioload and microbial prevalence from the DFP downstream indicated that the effluent contained some micro-organisms and provided nutrients for microbial utilization.

Biofilm bioloads were high from DFP and increased further at the DSI and DSII. Again, these biofilm bioloads were higher than the water column biolads. Donlan (1) had described biofilm as collation points while Nitschke and Pastore (3) called them natural water filters. McPeter et al. (8), Richard et al. (5) and Bos et al. (7) agree with these assertions. Thus, aquatic organisms aggregate at biofilms, the interaction of which provides more nutrients, safety and condusive habitat.

Donlan (1) and Bos et al. (7) stated that attachment of micro-organisms to surface is a very complex process with many variables affecting the outcome. Generally, attachment will occur most readily on surfaces that are rougher, more hydrophobic and coated films (Kelly et al. (30), Buswell et al. (4). However, Applegate and Bryers (13), Donlan (1) and Richard et al. (5) attribute high biofilm bioload to high water column bioload, high microbial nutrients, and availability of attachment surfaces. These 
factors therefore explain the gradient in biofilm bioloads observed in this work. Microbial utilizable nutrients, microbial flora (prevalence and diversity) and good growth conditions were more available in the DSI followed by DSII hence the observations.

Observations in the various bacterial groups showed that CEUB were present in the water before the discharge of the effluent into the water. This confirms the ubiquity of these microorganisms. However, the presence of the cassava effluent stimulated their growth as observed downstream. The coliforms were the most adversely affected as they could not metabolize the effluent. This result was buttressed by the screening for cassava effluent utilization. In other words, the survival of most coliforms in the water and biofilm was based on interrelationship with other bacterial species especially the CEUB. The CEUB produce intermediates from metabolizing the waste, which were utilized by other organisms.

In all the sampling points, wood surfaces had the highest bioload, followed by the plastic before glass and metallic surfaces. Bendringer et al. (31) and Pingle and Fletcher, (32) had reported that Teflons and wooden surfaces have high biofilm formation capacity. It could therefore be said that wood and plastics pose the greatest problems (i.e support) in biofilm formation in Oloshi River (33). This is because of the high biofilms bioload form on them $(34,35,36)$.

The effects of the physicochemical parameters in the formation of biofilms in Oloshi River could be attributed to only few factors as most of the parameters, did not give values that were significantly different along sampling points. Kelly et al. (30), Nitschke and Pastore (3) and Else et al. (12) lead much emphasis on $\mathrm{pH}$, temperature, humidity and salinity, which did not play much role in this study. However, this could be true in human body biofilm or water supply lines, not in an aquatic habitat that is virtually uniform in $\mathrm{pH}$, temperature and salinity level. This work however agrees with Applegate and Bryer (13), Donlan (1) and Nitchke and Pastore (3) that microbial load, microbial nutrient, oxygen level and nature of attachment surfaces are the limiting factors in aquatic habitats. This then concludes that the cassava effluent affected the biofilm formation in Oloshi River.

\section{REFERENCES}

1. Donlan RM. Biofilms: Microbial life on surface Emerg. Infect. Dis. 2002;8(9):881-888.

2. Characklis WG, McPeters GA, Marsh KC. Physiological ecology in biofilm systems. In: characklis WG, Marshall KC, editors. Biofilms. New York: John Wiley \& Sons; 1990. p. 341-398.

3. Nitschke M, Pastore GM. Production and Properties of a surfactant obtained from Bacillus subtilis grown on cassava waste water Biores Tech. 2006;97(2):336-341.

4. Buswell CM, Hertihy HM, Marsh PD, Keevil CW, Leach, SA. Co aggregation among aquatic biofilm bacteria. J Appl Microbiol. 1997;83(4):477-484.

5. Richard AH, Gilbat P, Handley PS. Influence of growth environment on coaggregation between freshwater biofilm bacteria. J Appl Microbiology. 2004;96 (6):1367-1373.

6. Malik A, Kakii K. Intergeneric coaggregations among Oligotropha carboxidovorons and Acinetobacter species present in activated sludge FEMS Microbiol Lett. 2003;224(1): 23-28.

7. Bos R, Henny C, Henk JB. PhysicoChemistry of initial microbial adhesive interactions- its mechanisms and methods for study. FEMS Microbial Rev. 1999; 23(2):179-230.

8. McPeters PBH, Lisk JT, Broadway SC. Rapid direct methods for enumeration of specific active bacteria in water and biofilm. J Appl Microbiol. 1999;85(1):1935-2005.

9. Parsek MR. Bacterial Biofilms: An emergency link to Disease pathogenesis. Ann. Rev Microbiol. 2004;57:677-701.

10. Sterrant PS. Theoritical aspects of antibiotic diffusion into microbial biofilms Antimicrob. Ag Chemotherop. 1996;40:2517-2522.

11. Wetland EZ, Stewart PS., Huang CT., McPeters GA Spatral variations in growth rate within Klebsiella pneumoniae colonies and Biofilms. Biotech Prog. 1996;12:316-321. 
12. Else TA, Pantle CR, Amy PS. Boundaries for biofilm formation: Humidity and Temperature. Appl Environ Microbiol. 2003;69(8):5006-5610.

13. Applegate DH, Bryer JB. Effects of carbon and Oxygen limitations and calcium concentrations on Biofim removal processes. Biotechnology and Bioengineering. 2004;37(1):17-25.

14. APHA Standardf methods for examination of water and waste water $18^{\text {th }}$ ed. Washington: American public Health Association; 1998.

15. Brudburg GM., Egan. SV, Bradburg JH. Determination of all forms of cyanogens in cassava roots and cassava products using picratge paper kits. J Sc Food Agric. 1999;79:593-601.

16. Chessbrough M. Laboratory Manual for tropical countries: Microbiology ECBS edition. London: Tropcal Health Techno$\operatorname{logy} \&$ Butter Worth; 2001. v. 2.

17. Adewoye SO, Fawole OO, Owolabi OD, Omotosho JS. Toxicity of cassava waste water effluents to African catsion Clarias gariepinus (Burchell; 1822). Ethiop J Sc. 2005;28(2):190-194.

18. Chinyere GC. Effects of effluents from cassava processing plants on soil cyanite level. A case study of Okigwe in Imo State and Orim Imenyi in Aba State J. Vis Hlth Sc. 2001;3:88-92.

19. Nwaugo VO, Onyeagba OM. Effects of calcium carbide wastes on soil Nitrifying bacteria in Okigwe, Imo State J. Appl Sc. 2004;7:4451-4458.

20. Nwabueze TU, Odunsi FO. Optimization of process conditions for cassava (Manihot esculenta) lafun production. Afr J Biotech. 2006;6(5):603-611.

21. Akanni, NP, Nmedo SA, Iheomanalu IN. Effects of cassava processing effluents on the microbial population or a physicochemical properties of loamy soil. In: $39^{\text {th }}$ Annual conf. Nig. Soci. Microbiol,. Nigeria: Nassarawa State University, Keffi, Nassarawa State; 2006.
22. Abiona OO, Sanni LO, Bamgbos O. An evaluation of microbial load, heavy metals and cyanide contents of water sources, effluents and peels from three cassava processing locations. J Food Agric Environ. 2005;3(1):207-209.

23. Oyewole OB, Odunfa SA. Characterization and distribution of lactic acid bacteria in cassava fermentation during fufu production. J Appl Bacteriol. 1992;68:148-152.

24. Desse G, Taye M. Microbial load and microflora of cassava (manihot exculentga crantz) and effect of cassava juice on some food borne pathagens. J Food Tech Afr. 2001;6(1):21-24.

25. Nwachukwu E, Otukunefor TU. Seasonal changes in sanitary bacterial quality of surface water in a rural community of Rivers State, Nigeria. Nig J Microbiol. 2003;17(2):110-114.

26. Prescot LM., Harley JP, Klein DA. Microbiology. $5^{\text {th }}$ ed. Boston: McGraw Ahill; 2001.

27. Nwaugo VO, Onyeagba RA, Obiekezie SO, Ugbogu OC Effects of Petroluem produced (formation) water on some farmland Bacteria in Egbema. River State, Nigeria. Int J Biotech Alli Sc. 2006b;1(1):31-36.

28. Nwaugo VO, Onyeagba RA, Nwachukwu NC. Bacteriological quality of cercarie (Schistosomia heamatobium) infested abandoned quarry pit water J. Sc Engr Tech. 2006b; 13(2):6697-6706.

29. Ezenobi NO, Okpokwanli GSC. Bacterial Flora \& Physicochemical characteristics of hospital sewage in Port Harcourt City. Nig J Microbiol. 2004;18(1):277-283.

30. Kelly JI. Turng B, Williams HN, Baer ML. Effects of Temp. Sanitry and substrate in the colonization of surfaces in sites by aquatic Bdellovibrios Appl environ Microbiol. 1997;63(1):84-90.

31. Bendringer B, Rijnaaris HHM, Altendorf K, Zehinder AJB. Physico-chemical cellsorface and adhesive properties of coryneform bacteria related to the presence and chain length of myriolic acids. Appl Environ Microbiol. 1993;59:3973-3971. 
32. Pingle JH., Fletcher. M. Influence of substratum wetability on attachment of freshwater bacteria to solid surface. Appl Environ Microbiol. 1983;45:811-117.

33. Richard AH, McBain AJ, Ledden RG., Handley PS, Gilbert P. Coaggregation between freshwater bacteria within biofilm and planktonic communities. FEMS Microbiol Lett. 2003;220(1):133-140.

34. Aderiye JB, Olududro AO, Owolabi OA. Biochemical and Microbialogical composition of fermented cassava tuber and survival of pathogenic staphylococcus aureus in garri. J Appl Envi Sc. 2005;1:1-5.

35. Fletcher M. Attachment of Pseudomonas fluorescens to glass and influence of electrolyte on bacterium substratum. Seperation distance. J Bacteriol. 1988; 170:2027-2030.

36. Cochran WL, McPeters GA, Stewort PS. Reduced susceptibility of thin Pseudomonas aeruginosa biofilms to hydrogen peroxide and monochloramine. J Appl Microbiol. 2000;88(1):22-30.

Received: 05/15/2006

Recebido: 15/05/2006

Accepted: 10/27/2006

Aceito: 27/10/2006 